PRODUCTION

ENGINEERING ARCHIVES
2016, Vol. 13, No 4, pp 2-6

ISSN 2353-5156 (print version)

ISSN 2353-7779 (online version)

\title{
Employees motivation in two wood industry companies in Croatia
}

\author{
Denis Jelačić ${ }^{1}$, Josip Faletar ${ }^{2}$ \\ ${ }^{1}$ Faculty of Forestry, Svetosimunska 25, HR-10000 Zagreb, Croatia, +385 123524 83; djelacic@sumfak.hr \\ ${ }^{2}$ Spačva, d.d., Duga ulica 181, HR-32100 Vinkovci, Croatia; jfaletar@inet.hr
}

\begin{abstract}
This research analysed the motivating and demotivating factors amongst employees in two wood processing companies in Croatia. Research was conducted over the year 2014 and 2015, during the economic recovery of the companies and Croatian economy in general. Research was conducted with a survey using a questionnaire containing six questions with multiple choice statements. The questions were closed-ended, and respondents used the Likert four-level scale of importance for each statement. A total of 180 employees were surveyed, and results were statistically processed by using the $\chi^{2}$ - test and cluster analysis. This study established that the motivation factors most important to employees between researched companies are significantly different. Employees were most concerned about social needs. Also, employees consider psychological circumstances of work to be very important. Employees' overall motivation can be linked to higher efficiency and higher quality production and business results, and such research should be conducted more often.
\end{abstract}

Key words - wood processing, furniture manufacturing, employee motivation, demotivating factors

\section{Introduction}

To achieve a quality production result without the influence of technical-technological factors one of the most important factors to consider is employees' motivation for work. Motivated employees come to work with enthusiasm and a wish to fulfill their daily obligations in the most satisfying way because it guarantees that their business results would be on the level required, satisfaction with their results would be higher, and their salaries would be bigger. Unmotivated employees very seldom fulfill their obligations, so their production and business results are on a much lower level than required by the company or by the market (JELAČIĆ D. ET AL. 2010).

There are two groups of motivating theories: (1) motivation of contents and (2) motivation of the process. The first group of theories researches the factors that motivate towards a certain behaviour, and the second group of theories studies the reasons behind a certain behaviour. Among the contents theories, the most recognized are the Maslow theory of needs, and the Glasser theory of choice. It is assumed that all human behaviour is pointed towards satisfying one's basic needs (LIPIČNIK B. 1998; GLASSER W. 1999, GLASSER W. 1994, KROPIVŠEK J. ET AL. 2011, JELAČIĆ D. ET AL. 2008). Knowing the profile of a person's needs can help form the basis for making the right approach for efficient and successful leadership (KROPIVŠEK J. 2007, JELAČIĆ D. ET AL. 2007). Herzberg gives one of those main theories, which has two main parts, the factors or motivators and the hygienic factors, which help maintain the standard level of satisfaction (MožINA S. 1998). 
Among the different process theories there is the theory of a problem, which is based on a statement that people are willing to solve problems. A problem automatically initiates some kind of reaction from an employee (LIPIČNIK B., MOŽINA S. 1993). The HackmanOldhamer model of enrichment is based on three key psychological circumstances, the importance of work, responsibility and knowing results, which all have an influence on motivation at the workplace (LIPIČNIK B., MožINA S. 1993). Fromm (Fromm E. 1996) gives a theory that says people work because they either want to have something or because they want to live up to be somebody/something one day.

Some newer research within companies for wood processing and furniture manufacturing (KROPIVŠEK J. 2003, KROPIVŠEK J., ROZMAN R. 2007) reveals the presence of organizational culture within a workplace, where the main goal is to motivate employees, which can represent an additional problem under certain given circumstances. It can be stated that almost all motivational factors lay in the hands of management. The main question remains: does management know how to use them (MožINA S. 1998)? Motivation means that somebody does something because he or she wants to do so, and what management has to do is to motivate and stimulate him or her in such a way (HERZBERG F. 2008, GeORGE J. M., JONES G. R. 1999). Motivation is the process of awakening a person's drive to pursue activities, with attention to certain details and regulation to achieve a certain goal while overcoming obstacles along the way (JELAČIĆ D. AT AL. 2010). It can be said that motivation contains factors such as enthusiasm, wish, intention, persistence, etc., which motivate and point ones behaviour in a certain direction (DAFT L. R. ET AL. 2000). Previous research has shown that human activities are motivated by one or many known and sometimes unknown complicated factors (MožINA S. 2002). There are individual factors that influence human activities and they are very often part of human social life. Therefore, some routine motivating approaches may prove to be ineffective, because they are not adapted to each individual person within a company (LIPIČNIK B. 1998). The main goal of these activities aims to satisfy the wishes and expectations of one individual person, which are formed, based on his or her own material and social needs, desire for re- spect, independence, personal growth and development.

The presented ideas have led to the empirical research in two wood processing companies. The aim was to establish what motivating factors are most important to employees and their level of importance in two different companies.

\section{Methodology of research}

The research method for collecting the data was a survey conducted by means of a questionnaire for employees consisting of 6 questions. The conditions of key presumptions of different motivational theories were checked within the questionnaire. The questions were closed-ended, and respondents were using a fourlevel scale of importance for each statement: number 1 meaning never, 2 meaning sometimes, 3 meaning often, and 4 meaning always. A total of 180 employees (n) were surveyed in each of two wood processing companies. The survey was conducted over the years 2014 and 2015.

The differences in the frequency of answers given by employees between two companies were tested by the $\chi^{2}$-test for each individual question. The hypothesis $\mathrm{H}_{0}$ was that the distributions of answers to the same question given in both companies were equal. The test showed that there was a statistically significant difference between distribution of all answers given in two different companies (for all tested values $\mathrm{p}<0.001$ ). The study aimed at establishing which answers to the questions given were closer to each other than others. Therefore a cluster analysis was conducted.

The clustering method was used to find distances between the questions. For computing the distances between the questions, the percent disagreement measure distance equation, $(x, y)=\left(\right.$ number of $\left.x_{i} \neq y_{i}\right) / i$ was used due to the categorical nature of the answers. For the clustering algorithm the hierarchical single linkage known as the nearest neighbor method was used. In this method the distance between two clusters is determined by the distance of the two closest objects within the different clusters $d\left(C_{i} U_{j}, C_{k}\right)=$ min. $\left(\mathrm{d}\left(\mathrm{C}_{\mathrm{i}}, \mathrm{C}_{\mathrm{k}}\right), \mathrm{d}\left(\mathrm{C}_{\mathrm{j}}, \mathrm{C}_{\mathrm{k}}\right)\right)$. All statistical analysis and graphical presentations were conducted using the STATISTICA 10.0 statistical software. 


\section{Results}

Using the $\chi^{2}$ - test (Pearson's chi-squared test and $\mathrm{p}$-values, where $\mathrm{p}<=0.001$ meaning that the differences are "very highly significant" (99.9\%), where $0.001<\mathrm{p}<=0.01$ meaning that the differences are "highly significant" $(99.0 \%)$, where $0.01<\mathrm{p}<=0.05$ meaning that the differences are "significant" (95.0\%), and where $\mathrm{p}>0.05$ meaning that the difference is "non-significant" $(90.0 \%)$ ), it was established that all the differences for all the questions were highly significant. Therefore, to establish the relationships between answers, the cluster analysis was used. Some of the results of the cluster analysis are given in the following graphs.
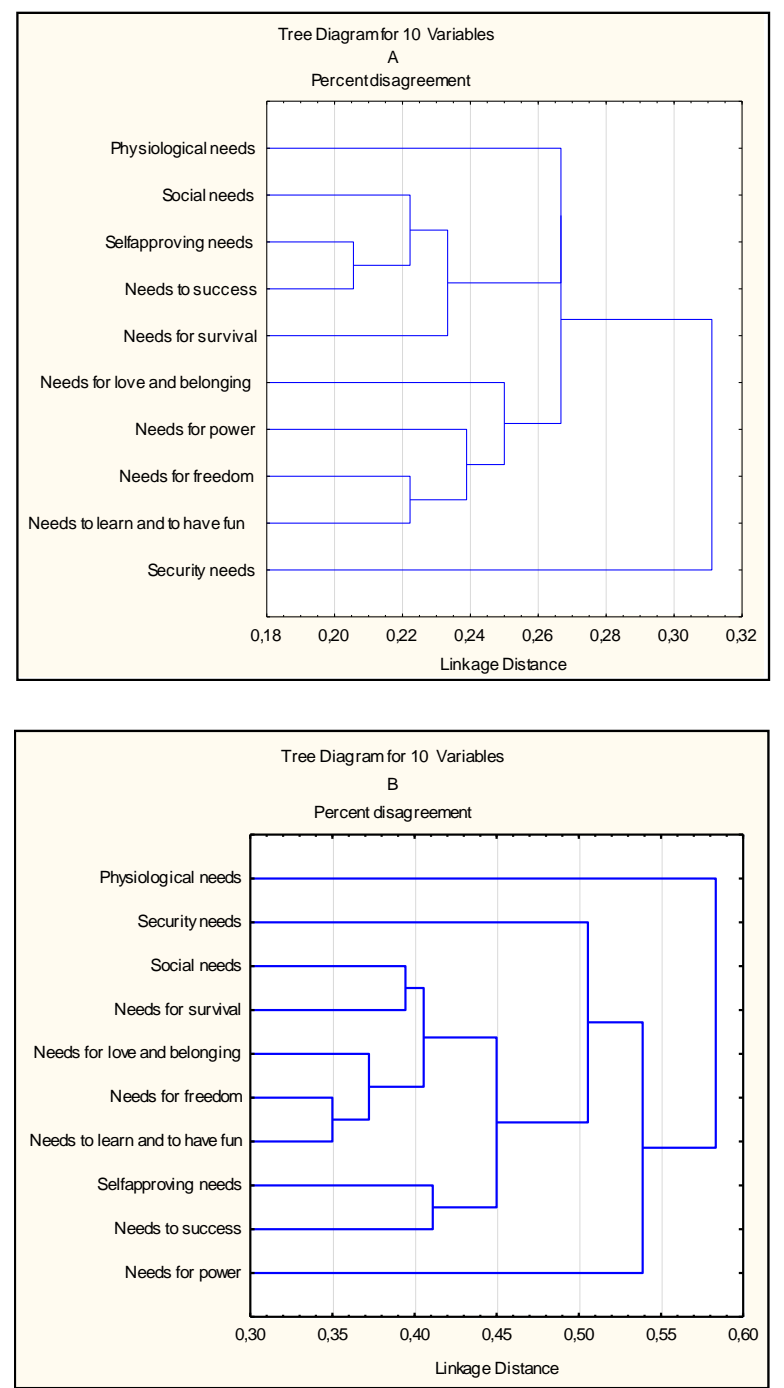

Fig. 1. Tree diagrams for the answers to question 1 (Which employees' needs do managers pay most attention to while managing?) for companies $A$ and $B$.
Figure 1 shows that there was a strong relationship between self-approving needs and the need for success in company A, while there is a strong connection between the need for freedom and the need to learn and to have fun in company $\mathrm{B}$.
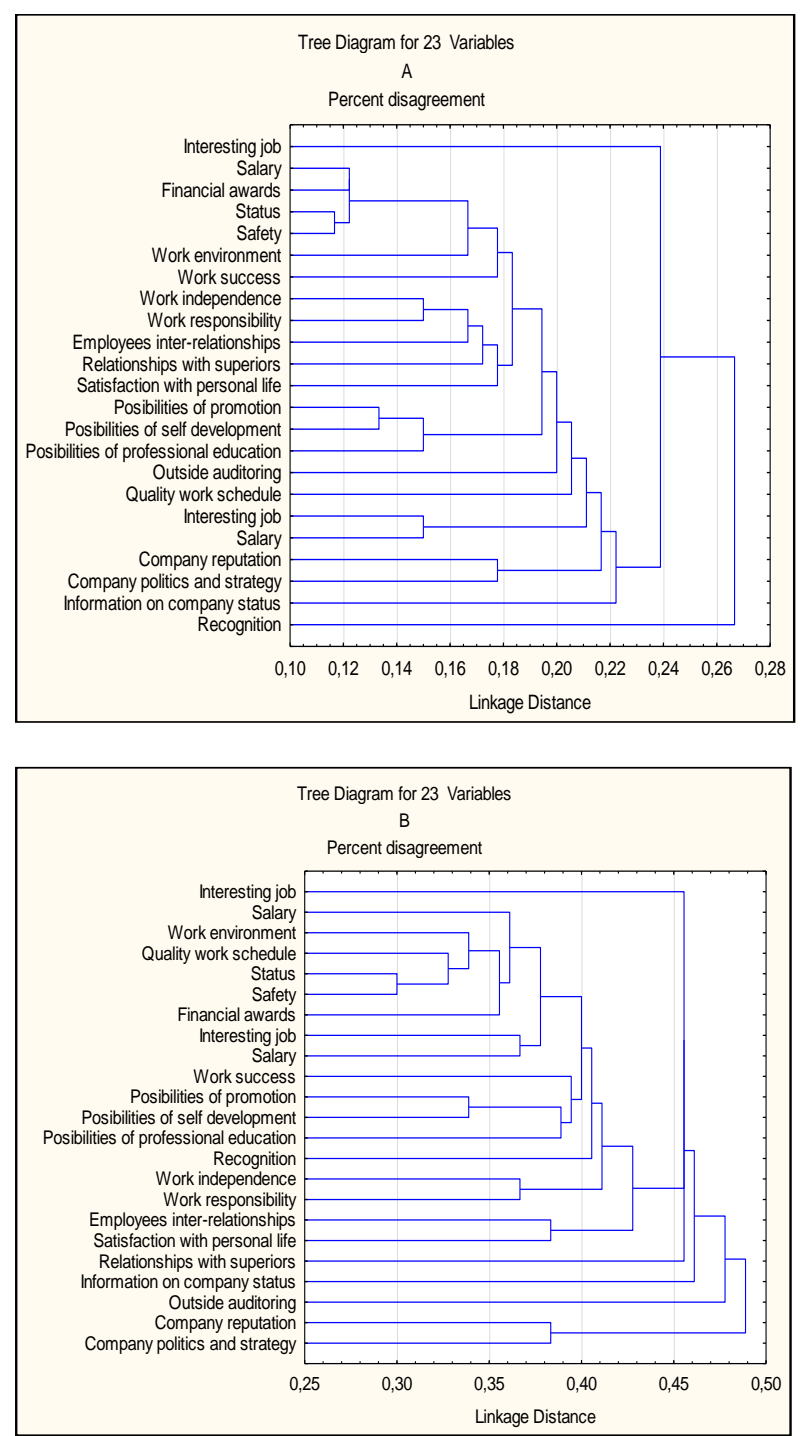

Fig. 2. Tree diagrams for the answers to question 2 (Which of these factors are important in motivation?) for companies $A$ and $B$.

Figure 2 shows that the strongest relationship in both companies was between needs for status and safety, but the linkage distance is significantly different for each of the companies in the research. Also, in company A the next two needs in strongest relationship with status and safety are salary and financial gratification. In company B the in strongest relationship with status and safety is a need for quality work schedule. It 
means that in company A employees are more interested in physiological needs while in company B they are more interested in social needs.

Answers to question 3 (Can a Problem Increase Your Activity (Motivate You)?) show the way that employees think about a problem as a motivator, and in both companies employees strongly connected a problem as a motivator and special conditions required to solve the problem. Again, the significant difference between two companies is the linkage distance between two answers (in company A the distance was 0.344 , while in company $B$ it was 0.530 ).

The linkage distance between two answers to the question 4, "Why do people work?," was significantly different between two companies. While employees in company A marked "having something" with higher average grade than employees in company B (3.68 comparing to 3.54), for "recognition" the average grade in company B was higher than in company A (2.85 comparing to 2.61 ).

Results of the cluster analysis for the question, "How psychological circumstances influence work (question 5)," show that employees in both companies consider sense of responsibility and work importance very important, but again the significant difference between two companies in the linkage difference between answers (the average grade of answers).

The last question, can be summarized by the following results in Fig. 3. Regarding demotivating factors and their presence in the company, employees considered different factors as more present in company A than those in company B. The strongest correlation is between the reprehending of employees and use of punishment in managing process, followed by a connection between less work to do and shortening of work hours in company A. In company B the strongest connection was between the use of punishment in managing and the creation of tension amongst employees, followed by less freedom at work.
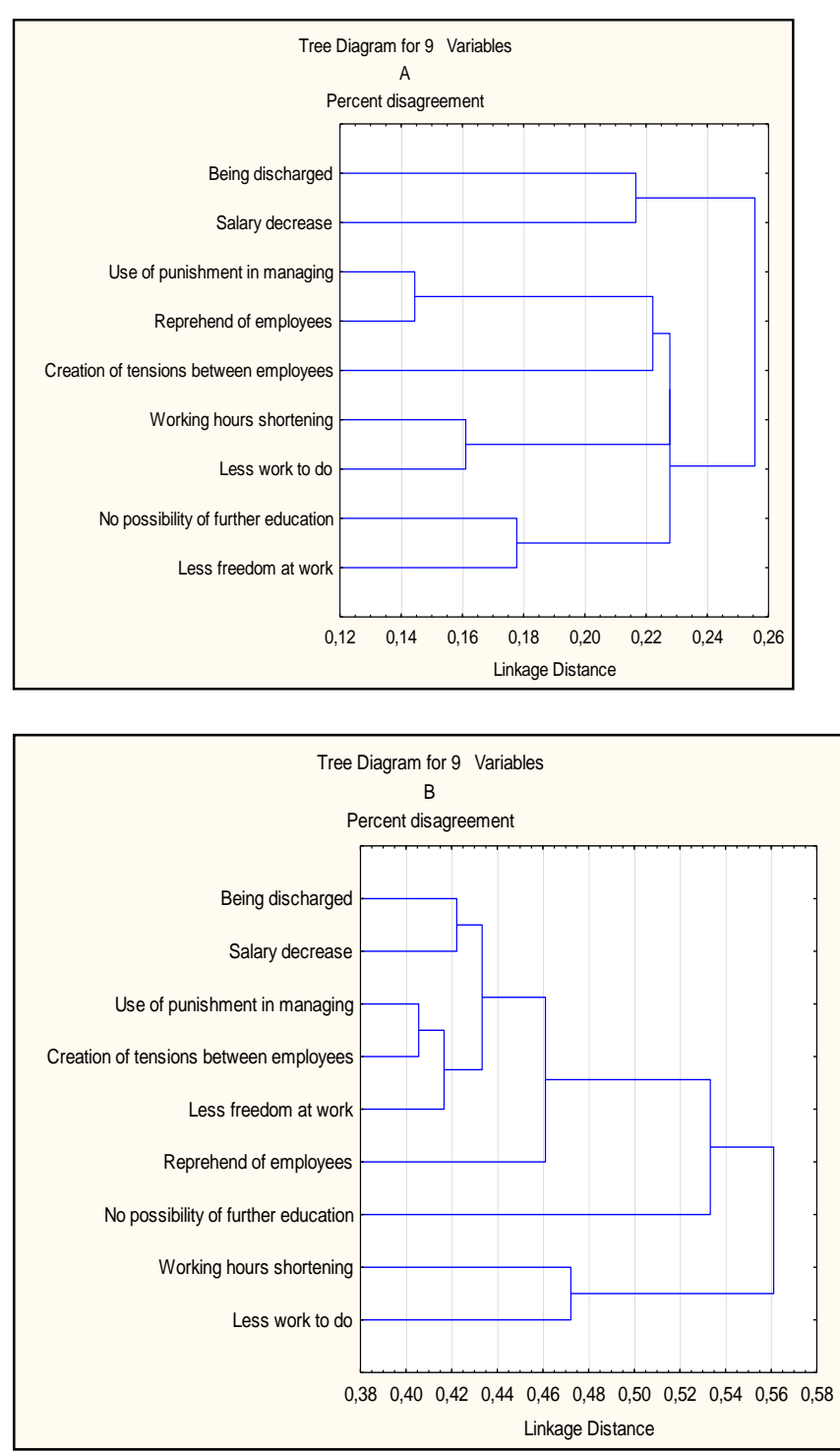

Fig. 3. Tree diagrams for the answers to question 6 (At what level do you notice demotivating factors in your company?) for companies $A$ and $B$.

\section{Conclusion}

The aim of this research was to establish the differences between the motivation of employees in two wood processing companies. Research discovered that the differences between all given questions and answers were statistically significantly different, so the cluster analysis was conducted to establish the linkage distance between answers to all the questions separately for both companies in research.

The study discovered that employees consider different motivation factors as important in different companies. Which motivating factors are more impor- 
tant to employees in different companies mostly depends on fulfilling of social and physiological needs, meaning that grading on importance of particular motivating factor depends on the work environment, managing skills of superiors, interrelationships between employees, work responsibilities, as well as on salaries and security of the job.

Demotivating factors and their presence in companies also have a significant influence on employees' satisfaction and motivation to work harder. Among demotivating factors employees mostly refer to managing skills of superiors, meaning they consider use of punishment in managing process the most important demotivating factor.

The next research of this type should be conducted in a year or two years from now, to investigate if a changed and improved work environment or some different managing skills among superiors, have a better or any different influence on motivating and demotivating factors in companies in research.

\section{Literature}

1. BRyAn L., FARRELl D. 2008. "Leading through uncertainty," McKinsey \& Company (http://www.vedzen.com/mackenzie).

2. CHARAN R. 2008. Leadership in the Era of Economic Uncertainty: Managing in a Downturn (1st Edition), McGraw-Hill, New York.

3. DAFT L. R., MARCIC D. 2000. Understanding Management, London: Thomson learning.

4. Fromm E. 1996. To Have or to Be?, Continuum International Publishing Group, New York.

5. GeORGE J. M., Jones G. R. 1999. Understanding and Managing Organizational Behaviour, $2^{\text {nd }}$ edition, Addison-Wesley, Reading, MA.

6. Glasser W. 1994. The Control Theory Manager, Harper Business, New York.

7. Glasser W. 1999. Choice Theory: A New Psychology of Personal Freedom, Harper Perennial, New York.

8. Herzberg F. 2008. One More Time: How Do You Motivate Employees?, Harvard Business Press, Boston.

9. Jelačić D., Galajdova V., Sujova A. 2007. "Employees satisfaction in wood processing plants in Slovakia and Croatia, Human Resource Management \& Ergonomics 1(3), 15-23.
10. JelaČIĆ D., Grladinović T., PirC A., OBlaK L. 2010. "Motivation factors analysis in industrial plants," Strojarstvo 5(3), 349-361.

11. Jelačić D., Grladinović T., Sujova A., Galajdova V. 2008. "Motivirajući čimbenici u preradi drva i proizvodnji namještaja [Motivation factors in wood processing and furniture manufacturing]," Drvna Industrija 59(1), 11-21.

12. KROPIVŠEK J. 2003. "The impact of human resources management and organizational culture on adaptability of Slovenian wood-industry firms," Zbornik Gozdarstva in Lesarstva, no. 70, 5-29.

13. KROPIVŠEK J., JELAČIĆ D., GROŠELJ P. 2011. "Motivating employees of slovenian and croatian wood industry companies in times of economic downturn," Drvna industrija 62(2), 97-103. (DOI: 10.5552/drind.2011. 1040).

14. KROPIVŠEK J., ROZMAN R. 2007. "Organisational model of a globally oriented wood industry company," Zbornik Gozdarstva in Lesarstva, no. 83, 15-21.

15. LIPIČNIK B. 1998. Ravnanje z Ljudmi pri Delu [Human Resource Management at Work], Gospodarski vestnik, Ljubljana.

16. LIPIČNIK B., ŽINA S. 1993. Psihologija v Podjetjih [Psychology in Companies], Ljubljana, DZS.

17. MožINA S. 1998. "Zadovoljstvo zaposlenih in motivacija za poslovno odličnost [Employees' satisfaction and motivation for business effectiveness]," Industrijska Demokracija 5-8.

18. MožInA S. 2002. Managenet Kadrovskih Virov [Management of Human Resources], Fakulteta za organizacijske vede, Kranj.

19. Mussa M. 2010. "Global economic prospects as of September 30, 2010: A moderating pace of global recovery". Peterson institute for international economics, (http://piie.com/publications/papers/mussa20100930.p df). 